University of Nebraska - Lincoln

DigitalCommons@University of Nebraska - Lincoln

\title{
Effects of Groundwater Development on Uranium: Central Valley, California, USA
}

Bryant C. Jurgens

U.S. Geological Survey

Miranda S. Fram

U.S. Geological Survey

Kenneth Belitz

U.S. Geological Survey

Karen R. Burow

U.S. Geological Survey

Matthew K. Landon

U.S. Geological Survey

Follow this and additional works at: https://digitalcommons.unl.edu/usgsstaffpub

Part of the Earth Sciences Commons

Jurgens, Bryant C.; Fram, Miranda S.; Belitz, Kenneth; Burow, Karen R.; and Landon, Matthew K., "Effects of Groundwater Development on Uranium: Central Valley, California, USA" (2009). USGS Staff -- Published Research. 223.

https://digitalcommons.unl.edu/usgsstaffpub/223

This Article is brought to you for free and open access by the US Geological Survey at DigitalCommons@University of Nebraska - Lincoln. It has been accepted for inclusion in USGS Staff -- Published Research by an authorized administrator of DigitalCommons@University of Nebraska - Lincoln. 


\title{
ground water \\ Effects of Groundwater Development on Uranium: Central Valley, California, USA
}

\author{
by Bryant C. Jurgens ${ }^{1,2}$, Miranda S. Fram ${ }^{2}$, Kenneth Belitz ${ }^{3}$, Karen R. Burow ${ }^{2}$, and Matthew K. Landon ${ }^{3}$
}

\begin{abstract}
Uranium (U) concentrations in groundwater in several parts of the eastern San Joaquin Valley, California, have exceeded federal and state drinking water standards during the last 20 years. The San Joaquin Valley is located within the Central Valley of California and is one of the most productive agricultural areas in the world. Increased irrigation and pumping associated with agricultural and urban development during the last 100 years have changed the chemistry and magnitude of groundwater recharge, and increased the rate of downward groundwater movement. Strong correlations between $U$ and bicarbonate suggest that $U$ is leached from shallow sediments by high bicarbonate water, consistent with findings of previous work in Modesto, California. Summer irrigation of crops in agricultural areas and, to lesser extent, of landscape plants and grasses in urban areas, has increased $\mathrm{P} \mathrm{CO}_{2}$ concentrations in the soil zone and caused higher temperature and salinity of groundwater recharge. Coupled with groundwater pumping, this process, as evidenced by increasing bicarbonate concentrations in groundwater over the last 100 years, has caused shallow, young groundwater with high U concentrations to migrate to deeper parts of the groundwater system that are tapped by public-supply wells. Continued downward migration of U-affected groundwater and expansion of urban centers into agricultural areas will likely be associated with increased $U$ concentrations in public-supply wells. The results from this study illustrate the potential longterm effects of groundwater development and irrigation-supported agriculture on water quality in arid and semiarid regions around the world.
\end{abstract}

\section{Introduction}

The Central Valley is one of the most productive agricultural regions in the world, with a cash value of more than $\$ 20$ billion in 2007 (U.S. Department of Agriculture 2007). Seven counties within the Central Valley are among the top 10 counties in the United States for agricultural products sold (U.S. Department of

\footnotetext{
${ }^{1}$ Corresponding author: U.S. Geological Survey, California Water Science Center, 6000 J St Placer Hall, Sacramento, CA 95819; bjurgens@usgs.gov

${ }^{2}$ U.S. Geological Survey, California Water Science Center, 6000 J St Placer Hall, Sacramento, CA 95819.

${ }^{3}$ U.S. Geological Survey, California Water Science Center, 4165 Spruance Road, Ste 200, San Diego, CA 92101.

Received May 2009, accepted August 2009.

Journal compilation (c) 2009 National Ground Water Association. No claim to original US government works.

doi: 10.1111/j.1745-6584.2009.00635.x
}

Agriculture 2007). Nearly two-thirds of all groundwater withdrawals in California occur in the Central Valley, primarily for agricultural irrigation (Hutson et al. 2004; Maupin and Barber 2005). The San Joaquin Valley makes up the southern two-thirds of the Central Valley, and most of the population and associated municipal or public groundwater use is in the eastern San Joaquin Valley (ESJV). Reliance on groundwater as a source of drinking water in the ESJV is expected to increase with rapid population growth and diminishing availability of surface water supplies.

Uranium (U) concentrations above the California Maximum Contaminant Level (CA-MCL) of 20 picocuries per liter ( $\mathrm{pCi} / \mathrm{L})$ - approximately equivalent to the U.S. Environmental Protection Agency Maximum Contaminant Level (U.S. EPA MCL) of 30 micrograms per liter $(\mu \mathrm{g} / \mathrm{L})$ - has led to the removal of at least 23 public-supply wells (PSWs) from service within the last 20 years in the ESJV (based on data from the California 
Department of Public Health [CDPH] Database, accessed September 2008). Groundwater from several other wells affected by high $\mathrm{U}$ is either blended with water containing low $\mathrm{U}$ or removed by ion exchange to meet regulatory requirements (Ashton 2006).

Previous studies have shown that anthropogenically introduced contaminants, such as pesticides and nitrate, have degraded the quality of groundwater within the ESJV (Nightingale 1972; Schmidt and Sherman 1987; Domagalski 1997; Burow et al. 2008; Wright et al. 2004). The spatial distribution of these contaminants in groundwater is linked to patterns of fertilizer and pesticide use and their rate of application at the surface. In contrast to these agricultural contaminants, $\mathrm{U}$ is naturally abundant in soils and aquifer sediments in the ESJV and is not linked to the application of fertilizers or pesticides (Jurgens et al. 2008).

Uranium is mobile in oxygenated groundwater and generally only forms stable minerals in sulfate-reducing environments; formation of stable $U$ minerals in oxic environments requires very high concentrations of $U$ (greater than $1000 \mu \mathrm{g} / \mathrm{L}$ ). Uranium in oxic groundwater has a valence of $+6[\mathrm{U}(\mathrm{VI})]$ and will form the oxycation uranyl $\left(\mathrm{UO}_{2}^{+2}\right)$ in the absence of complexing ions, such as dissolved inorganic carbon (DIC) (Langmuir 1978). The aqueous concentration of $\mathrm{U}(\mathrm{VI})$ is normally limited by uranyl adsorption to iron oxyhydroxide coatings on sediment grains, clay mineral edges, or to organic matter (Hsi and Langmuir 1985; Waite et al. 1994; Davis and Curtis 2004; Catalano and Brown 2005). However, the presence of complexing ions, particularly DIC species, can increase the solubility and mobility of U(VI) (Langmuir 1978; Hsi and Langmuir 1985; Waite et al. 1994; Davis and Curtis 2004). Recent work has also shown that calcium can enhance desorption of uranyl-carbonate ternary complexes (Fox et al. 2006) and that the calcium-uranyl-carbonate complex, $\mathrm{Ca}_{2} \mathrm{UO}_{2}\left(\mathrm{CO}_{3}\right)_{3}^{0}$, may be the dominate species of dissolved U(VI) in calcium-rich groundwater systems (Bernhard et al. 2001).

Plant root respiration and microbial oxidation of organic matter in soils produce carbon dioxide $\left(\mathrm{CO}_{2}\right)$, resulting in $\mathrm{CO}_{2}$ partial pressures $\left(\mathrm{PCO}_{2}\right)$ in the soil zone that are greater than atmospheric pressure (Russell 1973). Water percolating through the soil equilibrates with the soil atmosphere by dissolving $\mathrm{CO}_{2}(\mathrm{~g})$ to form carbonic acid. The carbonic acid participates in mineral weathering reactions that increase DIC concentrations in water, primarily in the form of bicarbonate. Soil calcite will also dissolve under high $\mathrm{PCO}_{2}$ pressures and therefore can be an added source of DIC to water (Appelo and Postma 1996). Water that is not taken up by plants or evaporated from the soil eventually percolates to the groundwater system as recharge. ESJV climate is characterized by cool, wet winters and hot, dry summers; thus, under natural conditions, biological productivity is limited by the lack of soil moisture during the summer season. During the last 100 years, the ESJV has been extensively developed for agricultural use, and increasingly for urban use. Warmseason irrigation (March through September) of agricultural crops and urban landscapes has greatly increased biological productivity. It is our hypothesis that increased soil zone $\mathrm{P} \mathrm{O}_{2}$ beneath irrigated lands has resulted in increased bicarbonate concentrations in groundwater, and that this bicarbonate has enhanced the mobility of $U$.

In addition, the application of surface water and groundwater for agricultural irrigation and pumping from deep parts of the aquifer for irrigation and public supply has increased the rate of downward groundwater flow (Williamson et al. 1989; Phillips et al. 2007). The vertical movement of water from the water table to deeper parts of the groundwater flow system has increased by more than sixfold in many parts of the valley since development and caused head gradients to be in a downward direction almost everywhere (Williamson et al. 1989). It is also our hypothesis that these changes in groundwater flow patterns have caused $U$ concentrations to increase in many PSWs throughout the ESJV.

Because the developed portion of the ESJV aquifer system is largely oxic, uranium is expected to remain mobile in groundwater and therefore poses a significant threat to the long-term sustainability of groundwater as a potable source.

This paper describes the likely linkage between the development of groundwater resources in the ESJV since the 1850 s and temporal increases in $U$ concentrations in groundwater. Data collected by the U.S. Geological Survey (USGS) for the California Ground Water Ambient Monitoring and Assessment program Priority Basin Project (USGS-GAMA), data previously collected by the USGS National Water Quality Assessment (NAWQA) program and other USGS studies (USGS historical), and data compiled by the CDPH are used to demonstrate that high $\mathrm{U}$ concentrations are associated with shallow, modern-age groundwater that has high concentrations of bicarbonate. We show that bicarbonate concentrations in ESJV groundwater have increased with time and that bicarbonate is likely associated with warm-season irrigation return water. Finally, we show that U concentrations in the deeper portions of the aquifer system tapped by PSWs are increasingly affected by shallow Uladen groundwater that is driven downward in response to pumping. The paper also shows that irrigation and development of lands for agricultural and urban uses can mobilize inorganic contaminants that may otherwise be sequestered under natural conditions. The results of this paper therefore illustrate the potential long-term effects of groundwater development and irrigation-supported agriculture on water quality in arid and semiarid regions around the world.

\section{Description of Study Area}

The study area is the eastern half of the San Joaquin Valley, which occupies the southern two-thirds of the Central Valley of California (Figure 1). The Central Valley is a large, northwest-trending, asymmetric structural trough 


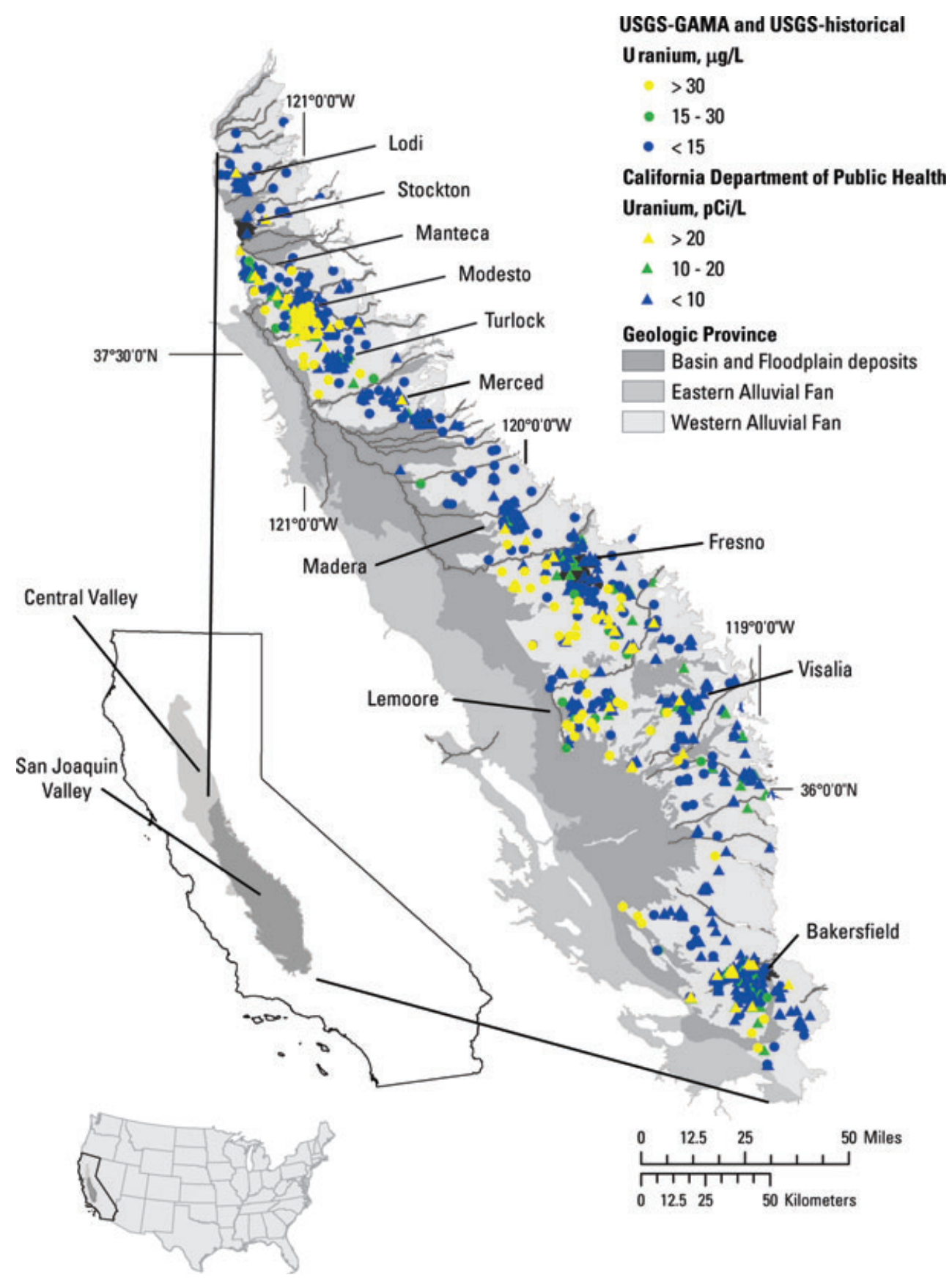

Figure 1. Location, physiographic features, and concentration of uranium in groundwater in the eastern San Joaquin Valley, California.

filled with marine and continental sediments up to 6 miles (mi) thick (Page 1986). The San Joaquin Valley is more than $248 \mathrm{mi}$ long and 19 to $56 \mathrm{mi}$ wide. East of the valley, the Sierra Nevada rise to an altitude of more than 8000 feet; west of the valley, the Coast Ranges form a series of parallel ridges up to 5000 feet high (Gronberg et al. 1998). Streams in the northern part of the San Joaquin Valley drain northward through the San Joaquin River to the San Francisco Bay; the southern part of the valley is a hydrologically closed basin.

Land-surface elevation rises from near sea level along the axial trough in the center of the valley to more than 300 feet at the top of dissected older alluvium near the valley margins. The climate is arid-to-semiarid, characterized by cool, wet winters and hot, dry summers. Mean annual precipitation ranges from less than 5 inches in the south to about 16 inches in the north (Gronberg et al. 1998).

\section{Hydrogeology}

Most groundwater withdrawals in the ESJV are from the upper 1000 feet of the basin-fill deposits. This part of the aquifer system mainly comprises a series of overlapping, stacked alluvial fan sequences deposited by streams draining the Sierra Nevada during the Holocene, Pleistocene, and Pliocene (Page 1986; Bartow 1991; 
Weissmann et al. 2005). These unconsolidated to semiconsolidated deposits are primarily derived from granitic rocks of the Sierra Nevada, with minor contributions from metavolcanic and metasedimentary rocks of the foothills (Page 1986; Bartow 1991). Beneath these sediments, Miocene and Pliocene deposits of andesitic volcanic detritus occur in areas draining the central and northern parts of the Sierra Nevada (Burow et al. 2004).

The aquifer system can be generally described as an unconfined to semiconfined aquifer underlain by a confined aquifer, particularly where separated by a regional lacustrine clay unit commonly referred to as the Corcoran Clay (Williamson et al. 1989; Bertoldi et al. 1991). Aquifer materials are dominated by eastern and western alluvial fan deposits interspersed with fine-grained basin and floodplain deposits, and coarser-grained fluvial deposits (Figure 1).

\section{Predevelopment Groundwater Flow}

A numerical model of the predevelopment (prior to about 1850) groundwater flow system in the Central Valley suggests that recharge and discharge averaged about 2 million acre-feet/year (Williamson et al. 1989). The groundwater system was recharged primarily by streams entering the valley near the mountain fronts, and to a lesser extent by precipitation. Groundwater generally moved from areas of recharge along the valley margins toward the central low-lying areas in the basin, where artesian conditions were common. Groundwater in the northern half of the ESJV discharged to the San Joaquin River and surrounding marshlands, whereas groundwater in the southern half discharged to perennial lakes in closed basins.

\section{Postdevelopment Groundwater Flow}

Since 1850, diversion of surface water from streams and intensive groundwater pumping associated with agricultural irrigation and urban growth have significantly altered the natural flow system (Davis et al. 1959; Page and Balding 1973; Londquist 1981; Williamson et al. 1989). Development of the groundwater resource accelerated after about 1930 due to improvements to the turbine pump, which allowed farmers to pump groundwater from greater depths at greater rates (Williamson et al. 1989). Currently, percolating irrigation water is the primary form of groundwater recharge, and pumping is the primary form of groundwater discharge (Faunt 2009). Recharge and discharge are now approximately 12 million acre-feet/year (Faunt 2009).

The application of irrigation water and pumping from deep parts of the groundwater system have caused increased downward movement of groundwater. Williamson et al. (1989) simulated the predevelopment and postdevelopment groundwater flow system and found that vertical flow had increased by more than six times in many parts of the valley. In addition, repeated irrigation and pumping cycles can cause water moving laterally along the regional groundwater flow direction to be pumped and reapplied at the surface multiple times (Burow et al. 2004).

The widespread use of groundwater has caused water level declines in many parts of the valley and has greatly reduced the extent of artesian conditions. The depth-towater table varies east-to-west and north-to-south. In the northern half of the valley, depth-to-water can be more than 60 feet near the valley margins in the east and less than 10 feet near the axial trough in the center of the basin. In the southern half of the valley, depth-to-water can be greater than 150 feet near the valley margins and less than 60 feet near the center of the basin (Faunt 2009). In urban areas, focused groundwater pumping and relatively low recharge rates have caused water level depressions within many cities in the valley (Bertoldi et al. 1991).

\section{Methods}

\section{Description of Well Networks and Datasets}

Between December 2004 and June 2008, 120 wells were sampled for $\mathrm{U}$ in the ESJV as part of the Priority Basin Project of the California Ground Water Ambient Monitoring and Assessment (GAMA) program (Bennett et al. 2006; Landon and Belitz 2008; Shelton et al. 2008, 2009; Burton et al. 2008). GAMA's Priority Basin Project is a statewide assessment of water quality in groundwater resources used for public supply in California (Belitz et al. 2003). The project is administered by the California State Water Resources Control Board and the USGS is the project's technical lead. Groundwater samples, primarily from PSWs, were collected for the GAMA program to assess groundwater quality in the ESJV. Samples for major ions, nitrate, and trace elements, including $\mathrm{U}$, were collected from 120 wells. Additional wells were sampled by the GAMA program but were not analyzed for U. Tritium $\left({ }^{3} \mathrm{H}\right)$ and dissolved noble gas samples were analyzed from 83 of the 120 wells and carbon-14 $\left({ }^{14} \mathrm{C}\right)$ was collected from 88 wells. This dataset is referred to as USGS-GAMA.

Additional chemistry data were compiled from previous and ongoing USGS investigations in the ESJV, including the San Joaquin-Tulare Basin NAWQA program (Dubrovsky et al. 1998; Burow et al. 1998, 2008), the NAWQA Transport of Anthropogenic and Natural Contaminants project (Jurgens et al. 2008), and the San Joaquin Valley Drainage program (Fujii and Swain 1995). Combined, these sources provided data from 230 wells analyzed for major ions and trace elements since 1989 in the study area; these data are publically available in the USGS National Water Information System (NWIS) database (http://waterdata.usgs.gov/ca/nwis/). The median U concentration was used for wells that had more than one analysis. A subset of the wells also had tritium data. This dataset is referred to as USGS historical.

The CDPH maintains a database of water quality data collected from public-supply sources for regulatory purposes. The database contains U data for 941 wells sampled between 1986 and 2006. The maximum U 
concentration from each well was used to describe the occurrence and distribution of high $U$ in PSWs in the ESJV. Most of these wells were sampled for U more than once. Because U was not widely collected from wells between 1986 and 1990 (less than $10 \%$ of the total number of wells), recent $U$ trends were examined with $U$ data beginning on January 1, 1990, and ending on December 31, 2005 (16 years).

\section{Sample Collection and Analysis}

USGS-GAMA data were collected in accordance with the protocols established by the USGS NAWQA program (Koterba et al. 1995) and the USGS National Field Manual (USGS, variously dated). These sampling protocols ensure that a representative sample of the raw groundwater resource is collected from each well and that samples are collected and handled in a way that minimizes the potential for contamination. All public-supply well samples were collected at discharge points upstream of any chlorination or well-head treatment systems. Detailed descriptions of sample collection procedures, analytical methods, and quality-assurance results, and compilations of data can be found in Bennett et al. (2006); Burton et al. (2008); Landon and Belitz (2008); and Shelton et al. (2008, 2009). Historical chemistry data from other USGS investigations in the ESJV were collected and analyzed using the same or similar methods.

Samples for major ions, nitrate, uranium, and other trace elements were analyzed at the USGS National Water Quality Laboratory (NWQL) in Denver, Colorado. Carbon-14 was analyzed at the University of Waterloo and IsoTrace Laboratory (Ontario, Canada) by accelerated mass spectrometry. The activity of ${ }^{14} \mathrm{C}$ - expressed as percent modern carbon (pmc) - is reported with a onesigma estimate of precision relative to the 1950 National Bureau of Standards oxalic acid standard. Samples for the noble gases, neon (Ne), argon (Ar), krypton $(\mathrm{Kr})$, and xenon $(\mathrm{Xe})$, were collected in copper tubes $(25-\mathrm{cm}-$ long, 3/8-inch [0.95] diameter) using reinforced nylon tubing connected to a hose bib at the wellhead. Copper tubes were flushed with groundwater and clamped at both ends to seal the sample. Tritium was collected in a 1L glass bottle with each noble gas sample. Tritium, Ne, $\mathrm{Ar}, \mathrm{Kr}$, and $\mathrm{Xe}$ were measured at Lawrence Livermore National Laboratory (LLNL). Tritium was determined by the helium in-growth method (Bayer et al. 1989). Helium was analyzed using a VG-5400 noble gas mass spectrometer; dissolved $\mathrm{Ne}, \mathrm{Kr}$, and $\mathrm{Xe}$ were analyzed using a quadrupole mass spectrometer and argon was measured using a high-sensitivity capacitive manometer (Beyerle et al. 2000; Moore et al. 2006; Cey et al. 2008).

Uranium data reported in the CDPH database were collected for regulatory compliance, and California regulates $U$ activity, rather than $U$ mass concentration. Uranium results from the CDPH database were analyzed using standard radiochemical methods and reported in pCi/L (U.S. Environmental Protection Agency 1980). These data were assumed to be adequate for describing the occurrence, distribution, and trends in $\mathrm{U}$ concentrations in those PSWs having $\mathrm{U}$ analyses. The mass to activity conversion factor in groundwater depends on the activity of each $U$ isotope, particularly the ratio of ${ }^{234} \mathrm{U}$ to ${ }^{238} \mathrm{U}$. Because the $U$ activity ratio (UAR) of ${ }^{234} U$ to ${ }^{238} \mathrm{U}$ is not constant in groundwater, the mass to activity conversion factor varies. Therefore, $U$ reported in activity units by the $\mathrm{CDPH}$ was not compared directly with $\mathrm{U}$ results reported in mass units by the USGS.

Nonparametric, rank-based methods were used for statistical analysis because the data were not normally distributed. The significance level $(\alpha)$ used for hypothesis testing was $5 \%(\alpha=0.05)$. Correlations were investigated using Spearman's method to calculate the rank-order correlation coefficient ( $\rho$, rho) between continuous variables. The Kruskal-Wallis rank sum test was used to test differences among groups (Conover 1980). If the KruskalWallis rank sum test indicated a significant difference in more than two groups, the multiple stage Kruskal-Wallis test was used to determine whether a significant difference exists between successive groups (Helsel and Hirsch 2002). The significance level used for the multiple stage Kruskal-Wallis test was $\alpha_{\mathrm{p}}=0.025$. The signed-rank test was used to evaluate the differences in matched pairs of data.

Reduction/oxidation (redox) conditions were evaluated on the basis of dissolved oxygen (DO), nitrate $\left(\mathrm{NO}_{3}^{-}\right)$, manganese $\left(\mathrm{Mn}^{2+}\right)$, iron $\left(\mathrm{Fe}^{2+}\right)$, and sulfate $\left(\mathrm{SO}_{4}^{2-}\right)$ concentrations using the classification scheme of McMahon and Chapelle (2008). Because redox processes in groundwater tend to segregate into zones dominated by a single electron-accepting process, the redox framework uses the concentration of the redox sensitive species above to assign the predominant redox process to groundwater samples. An automated workbook program was used to assign the redox classification to each sample (Jurgens et al. 2009).

Recharge temperatures for 83 samples were determined from dissolved $\mathrm{Ne}, \mathrm{Ar}, \mathrm{Kr}$, and $\mathrm{Xe}$ using methods described in Aeschbach-Hertig et al. (1999). Only modeled recharge temperatures having a probability greater than $1 \%$ were accepted $(P<0.01$; Aeschbach-Hertig et al. 2000).

Speciation of dissolved U, calculated partial pressure of carbon dioxide $\left(\mathrm{PCO}_{2}\right)$, and saturation indices of $\mathrm{U}$ minerals and calcite in groundwater were calculated using PHREEQC, version 2.15 (Parkhurst and Appelo 1999). Data for the following species were included in the calculations: calcium, magnesium, sodium, potassium, chloride, alkalinity, sulfate, fluoride, nitrate, phosphate, barium, and strontium. Not all samples had nitrate, phosphate, barium, or strontium data, although more than $90 \%$ of the samples had data for each of these constituents. The LLNL thermodynamic database, included with PHREEQC, was modified for speciation calculations. Formation constants for U complexes were updated using thermodynamic data reported by Grenthe et al. (1992), and ternary complexes of uranyl and carbonate with the alkaline earth metals reported by Dong and Brooks (2006) 
were added to the database. A two-site surface complexation model (SCM) was developed with the diffuse double layer model (Dzombak and Morel 1990) using PHREEQC. The surface species and formation constants for surface reactions were taken from Waite et al. (1994). The bidentate surface reaction expressions of Waite et al. (1994) were formatted for use with PHREEQC by Payne (1999) so that the mass action equation uses one mole of hydrous ferric oxide while the mole balance equation uses two. Model solutions contained $10^{-5} \mathrm{M} \mathrm{U}(\mathrm{VI})$ and aqueous U(VI) concentrations were calculated for $\mathrm{pH}$ values ranging from 6.25 to 9.5 , the predominant $\mathrm{pH}$ range of ESJV groundwater. Moles of iron were estimated from ten $0.5 \mathrm{M}$ HCl-hydroxylamine extractions (Jurgens unpublished data 2008). The average iron concentration was $80 \mathrm{mmol} / \mathrm{L}$ and was used to calculate site densities. The site densities were those of Waite et al. (1994): 0.8732 moles of weak sites per mole of iron and 0.0018 moles of strong sites per mole of iron. Three models were created for varying concentrations of total DIC: $10^{-3.0}, 10^{-2.5}$, and $10^{-2.0} \mathrm{M}$. Each of these models had two forms: one without calcium and one with calcium at $1.2475 \mathrm{mmol} / \mathrm{L}$ (50 mg/L), a typical concentration in ESJV groundwater.

Land use was classified using an "enhanced" version of the satellite-derived (30-m pixel resolution), nationwide USGS National Land Cover Dataset (Vogelmann et al. 2001; Price et al. 2003). This dataset has been used in previous national and regional studies relating land use to water quality (Gilliom et al. 2006; Zogorski et al. 2006). The data represent land use during approximately the early 1990s. The imagery is classified into 25 landcover classifications (Nakagaki and Wolock 2005). These 25 land-cover classifications were further classified into three principal land-use categories: urban, agricultural, and natural. Land-use statistics for circles with a radius of $500 \mathrm{~m}$ around each well were calculated for classified datasets using ArcGIS (version 9.2) (Johnson and Belitz 2009). Wells were then categorized by dominant land use. Mixed use was assigned where neither agricultural, urban, or natural land uses comprised more than $50 \%$ of the land surrounding the well.

\section{Results and Discussion}

\section{Spatial Distribution of Uranium in Groundwater}

Groundwater with high $U$ content has been found throughout the ESJV (Figure 1). U concentrations for the 350 wells from the USGS-GAMA and USGS-historical datasets range from less than the detection limit (0.04) to $2,500 \mu \mathrm{g} / \mathrm{L}$ (Table 1). Approximately $19 \%$ of the wells (65 of 350) had a concentration greater than the US-MCL of $30 \mu \mathrm{g} / \mathrm{L}$, and an additional $12 \%$ of the wells had $\mathrm{U}$ concentrations greater than one-half of the US-MCL.

PSWs from the CDPH database are not uniformly distributed across the ESJV and tend to be clustered in urban areas and along major transportation corridors (Figure 1). Approximately 11\% (103 of 941) of the PSWs had at least one $U$ analysis greater than the CA-MCL of $20 \mathrm{pCi} / \mathrm{L}$, and an additional $5 \%$ of the wells had at least one $U$ analysis greater than one-half of the CA-MCL. $\mathrm{U}$ concentrations ranged from less than the detection limit (1) to $102 \mathrm{pCi} / \mathrm{L}$. Of the $941 \mathrm{CDPH}$ wells, 848 wells remained active as of 2006. Twenty-three of the 93 inactive wells were abandoned because of high $\mathrm{U}$ concentrations.

Most of the $\mathrm{U}$ values greater than the CA-MCL in the CDPH dataset were in PSWs near Modesto, Fresno, and Bakersfield, major population centers in the ESJV. However, because the density of PSWs was also greatest in these areas, the clustering of high $U$ values may reflect increased sample density. The USGS-GAMA and USGS-historical datasets show a wider distribution of wells with U concentrations above the US-MCL. USGSGAMA wells were selected using a spatially distributed, randomized method (Scott 1990) to provide a statistically robust representation of the areal extent of the portion of the ESJV aquifer system used for public supply. The USGS-historical dataset was dominated by domestic and monitoring wells, which generally have perforation intervals in shallower portions of the aquifer than do PSWs. For example, the cluster of wells near Lemoore primarily includes monitoring and domestic wells. The USGS-GAMA and USGS-historical datasets therefore represent a larger portion of the aquifer system than the $\mathrm{CDPH}$ dataset, and show that groundwater with high $\mathrm{U}$ concentrations is indeed widespread in the ESJV.

The occurrence of groundwater with high U concentrations appears to be significantly greater in the ESJV than in other areas of the United States. In a recent survey of domestic wells in the United States (Focazio et al. 2006), U concentrations above $30 \mu \mathrm{g} / \mathrm{L}$ (US-MCL) were found in less than $4 \%$ of the wells (note that domestic wells are not subject to regulation). In contrast, $25 \%$ of the domestic wells in USGS-historical and USGS-GAMA datasets in the ESJV had U concentrations above the USMCL.

High concentrations of $\mathrm{U}$ may not be as widespread as nitrate is in ESJV groundwater, which is above the US-MCL $(10 \mathrm{mg} / \mathrm{L}$ as $\mathrm{N})$ in $32 \%$ of domestic wells and $24 \%$ of all the wells in the USGS datasets. However, the percentage of wells affected by high $U$ approaches that of nitrate and indicates that $U$ does pose a significant threat to the continued operation of many PSWs in the ESJV.

\section{Relation of Uranium Concentrations to Depth below Water Table and Age Tracers}

The USGS-GAMA and USGS-historical datasets include well construction information and can therefore be used to estimate the vertical distribution of $\mathrm{U}$ within the aquifer system. Monitoring wells had the highest $\mathrm{U}$ concentrations, highest percentage of wells above the USMCL, and the shallowest depths below the water table (Figure 2; Table 1). These wells are typically screened over short intervals (less than 5 feet) and provide water quality at discrete points in the aquifer system. Domestic wells, which tend to be located in rural areas, also had a high percentage of wells with $U$ greater than $30 \mu \mathrm{g} / \mathrm{L}$, but a lower median $\mathrm{U}$ concentration and greater depth 


\section{Table 1}

Summary of Uranium Concentrations in Groundwater from Different Well Types in Eastern San Joaquin Valley, California; U.S. Geological Survey National Water Information System (NWIS)

\begin{tabular}{|c|c|c|c|c|c|c|c|}
\hline \multirow[b]{2}{*}{ Well Type } & \multirow{2}{*}{$\begin{array}{l}\text { Number of } \\
\text { Wells with } \\
\text { U Analysis }\end{array}$} & \multicolumn{3}{|c|}{ Uranium $(\mu \mathrm{g} / \mathrm{L})$} & \multirow{2}{*}{$\begin{array}{c}\text { Number of } \\
\text { Wells with } \\
\mathrm{U}>30 \mu \mathrm{g} / \mathrm{L}\end{array}$} & \multirow{2}{*}{$\begin{array}{l}\text { Range in Depth below } \\
\text { Water Table to Top of } \\
\text { Uppermost Perforated } \\
\text { Interval (feet) }\end{array}$} & \multirow{2}{*}{$\begin{array}{l}\text { Median } \\
\text { Screen } \\
\text { Length }\end{array}$} \\
\hline & & Minimum & Median & Maximum & & & \\
\hline Observation & 98 & 0.09 & 18.0 & 2500 & $31(32 \%)$ & $0.66-307[55]$ & 5 \\
\hline Domestic & 122 & 0.04 & 8.7 & 503 & $30(25 \%)$ & $9.6-454[82]$ & 20.5 \\
\hline Public supply & 121 & 0.04 & 1.8 & 41.3 & $3(2.5 \%)$ & $7.0-917$ [140] & 211 \\
\hline Irrigation & 9 & 0.20 & 7.8 & 91.9 & $1(11 \%)$ & $42-557[160]$ & 175 \\
\hline All USGS data ${ }^{1}$ & 350 & 0.04 & 6.7 & 2500 & $65(19 \%)$ & $0.66-917[98]$ & 50 \\
\hline
\end{tabular}

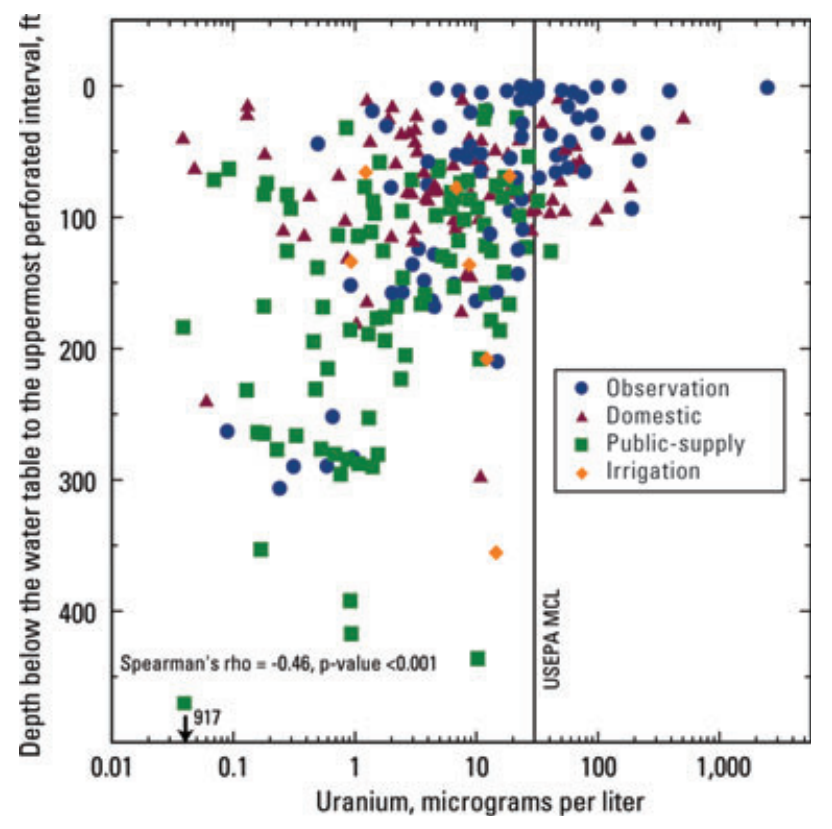

Figure 2. Relation between uranium in groundwater and depth below the water table to the uppermost perforated interval among well types in the eastern San Joaquin Valley, California.

below the water table than monitoring wells. PSWs had the lowest median $U$ concentration. These wells tend to be located within urban areas, are perforated at deeper depths than monitoring and domestic wells, and generally have long screens (greater than 50 feet). PSWs in the ESJV typically withdraw water at rates between 200 and 2,500 gpm, much greater than those for domestic wells. Irrigation wells had the greatest depth below the water table of all the wells, but had higher U concentrations than PSWs. However, only nine irrigation wells were sampled for $U$ in this study, and therefore may not accurately represent $U$ concentrations in irrigation wells throughout the ESJV.

Uranium concentrations were significantly correlated to depth below the water table with the highest concentrations near the water table and decreasing with depth
(Figure 2; Spearman's rho $=-0.46, P$-value $<0.001$ ) Groundwater having U above $30 \mu \mathrm{g} / \mathrm{L}$ occurred in wells having perforated intervals beginning less than 150 feet below the water table, and most groundwater above 10 $\mu \mathrm{g} / \mathrm{L}$ occurred in wells with perforated intervals starting less than 200 feet below the water table. Groundwater from less than 200 feet below the water table had a median $\mathrm{U}$ concentration of $8.4 \mu \mathrm{g} / \mathrm{L}$; that from greater than 200 feet had a median $U$ concentration of $0.73 \mu \mathrm{g} / \mathrm{L}$.

Uranium concentrations also were significantly higher in wells with ${ }^{3} \mathrm{H}$ concentrations greater than 1 tritium unit (TU) and ${ }^{14} \mathrm{C}$ greater than 90 pmc (Kruskal-Wallis test; $P$-value $<0.001$; Figure 3 ). ${ }^{3} \mathrm{H}$ activities greater than $1 \mathrm{TU}$ indicate the presence of groundwater recharged after 1950 and ${ }^{14} \mathrm{C}$ activities greater than 90 pmc indicate the likely absence of groundwater with residence times greater than about 1,000 years. Together, these two age-dating criteria identify "modern" groundwater, that is, groundwater that was recharged since large-scale agricultural and urban development began in the ESJV. The median $\mathrm{U}$ concentration in groundwater samples with ${ }^{3} \mathrm{H}$ greater than $1 \mathrm{TU}$ was $9.0 \mu \mathrm{g} / \mathrm{L}$, compared with $0.60 \mu \mathrm{g} / \mathrm{L}$ for samples with less than 1 TU. Likewise, the median $\mathrm{U}$ concentration in groundwater samples with ${ }^{14} \mathrm{C}$ greater than $90 \mathrm{pmc}$ was 7.2 and $0.93 \mu \mathrm{g} / \mathrm{L}$ for samples with less than 90 pmc. These results indicate that high U concentrations in the ESJV are preferentially associated with modern, shallow groundwater.

\section{Uranium Mobilization}

Source of Uranium

Uranium is naturally abundant in sediments in the ESJV, which are derived from granitic rocks of the Sierra Nevada. Aerial gamma-ray surveys of $U$ in the ESJV show that $U$ concentrations in surficial sediments range from 1.22 to $4.20 \mathrm{ppm}$ and average about $3 \mathrm{ppm}$ (Phillips et al. 1993). In contrast, surficial sediments of the conterminous United States have an average $U$ concentration of $1.83 \mathrm{ppm}$. The average abundance of $\mathrm{U}$ in the ESJV is above the 90th percentile of $\mathrm{U}$ for surficial sediments of the United States. Because most of the geologic formations used for domestic and public 

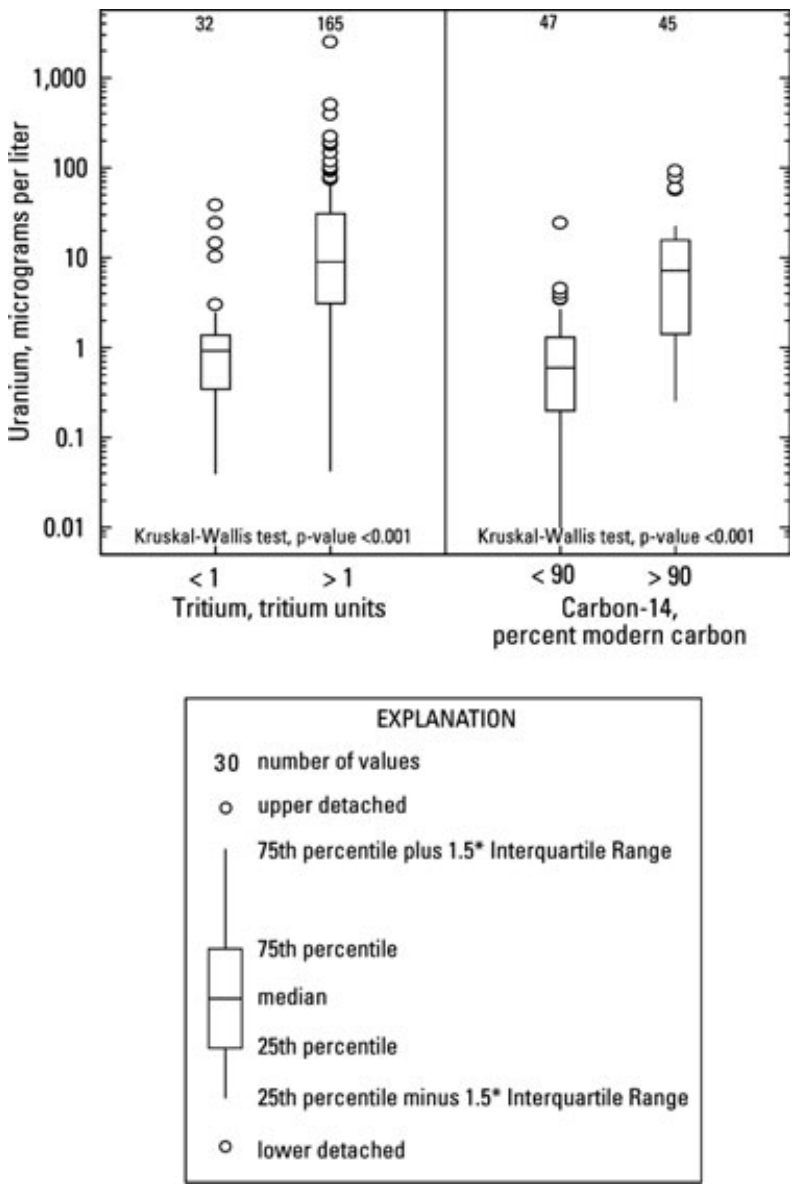

Figure 3. Uranium concentration in samples having tritium less than $(<) 1$ tritium unit (TU), tritium greater than $(>)$ $1 \mathrm{TU}$, carbon-14 $<90$ percent modern carbon (pmc), and carbon-14 > 90 pmc.

supply are also derived from the granitic rocks of the Sierra Nevada, it is probable that the concentration of $U$ in aquifer sediments is similar to the concentrations in surficial sediments. However, the amount of $U$ that may be easily mobilized is typically only a small fraction of the total $\mathrm{U}$ content of the sediment. This fraction is normally adsorbed to mineral surfaces on sediment grains, primarily iron oxide and oxyhydroxide coatings, and the edges of clay minerals (Hsi and Langmuir 1985; Waite et al. 1994; Davis and Curtis 2004; Catalano and Brown 2005).

Jurgens et al. (2008) measured the labile portion of $U$ in sediments from core collected in Modesto (Figure 1). U was extracted from aquifer sediment samples using a 0.1$\mathrm{M}$ sodium bicarbonate solution at a $\mathrm{pH}$ of 9.45 (Kohler et al. 2004). The labile portion of $U$ in aquifer sediments ranged from less than 0.02 to $0.11 \mathrm{ppm}(\mathrm{mg} / \mathrm{kg})$, although the bulk $U$ composition of the sediments was nearly constant. Leachates from the shallowest sediments (less than 60 feet below land surface [bls]) contained the least $U$, suggesting that some of the labile $U$ had already been leached out. Leachates from the deepest sediments (greater than 200 feet bls) contained the most $\mathrm{U}$, suggesting that deeper parts of the aquifer had not yet experienced leaching.
More strongly bound $\mathrm{U}$ was also extracted from sediments using $10 \% \mathrm{HNO}_{3}$ and ranged from 0.23 to $1.2 \mathrm{mg} / \mathrm{kg}$ and increased with depth below land surface (Spearman's rho $=0.75, P$-value $<0.03$; Jurgens et al. 2008). These results indicate that both the labile and more strongly bound fractions of $U$ of shallow sediments have experienced leaching. Inorganic carbon was undetectable (less than $0.01 \%$ ) in all sediment samples collected from the aquifer (Jurgens et al. 2008). Although calcite has been shown to host $U$ in its structure (Kelly et al. 2006), the amount of $U$ that could potentially be associated with undetectable levels of calcite in the aquifer would be minor in comparison to fractions associated with the labile and more strongly bound fractions.

Jurgens et al. (2008) also evaluated the potential for adsorption of $U$ to aquifer sediments under similar $\mathrm{pH}$ values and bicarbonate concentrations found at the depths from which the sediment samples were collected. Adsorption experiments for the shallower sediments (less than 180 feet bls) showed no adsorption of U. In contrast, the deeper sediments (greater than 200 feet bls) showed linear type adsorption of $U$. The difference in adsorption behavior was not likely because of a difference in abundance of adsorption sites for U. Iron oxyhydroxide coatings on mineral grains (the primary location of absorption sites) were dissolved from sediment samples using $0.5 \mathrm{M} \mathrm{HCl}-$ hydroxylamine solutions, and the iron concentrations of resulting leachates did not vary systematically with sediment depth or U-adsorption behavior (Jurgens unpublished data 2008). These results suggest that higher $U$ concentrations in shallower groundwater compared with deeper groundwater are because of differences in groundwater geochemistry with depth, not to reduction in the abundance of adsorption sites in the shallow sediments.

\section{Mechanism of Mobilization - the Role of Bicarbonate}

Three-hundred and ten of the 350 wells in the USGSGAMA and USGS-historical datasets had data for DO concentrations; DO data are not compiled by CDPH. Approximately $86 \%$ (268 out of 310) of the groundwater samples had DO concentrations above $0.5 \mathrm{mg} / \mathrm{L}$ and were classified as oxic in the McMahon and Chapelle (2008) classification system. Median concentrations of DO, $\mathrm{NO}_{3}^{-}, \mathrm{Mn}^{2+}, \mathrm{Fe}^{2+}$, and $\mathrm{SO}_{4}^{2-}$ in ESJV groundwater were $4.5,4.8,<0.02,<0.1$, and $22.7 \mathrm{mg} / \mathrm{L}$ respectively. Uranium in oxic groundwater had a median concentration of $6.5 \mu \mathrm{g} / \mathrm{L}$. Uranium was significantly lower in anoxic groundwater (median $=0.93 \mu \mathrm{g} / \mathrm{L}$; multiple stage Kruskal-Wallis rank sum test, $P$-value $=0.003$ ). The reduced mobility of $U$ under reducing conditions is likely because of reduction to U(IV) and the low solubility of U(IV) phases. Anoxic conditions occurred in less than $6 \%$ of wells and were mostly found in wells located near the basin and floodplain deposits (Figure 1). It is possible that some of the extremely high occurrences of $U$ near the center of the basin was caused by the oxidation of U(IV) minerals as a result of irrigation and groundwater pumping; although past studies have attributed some of the high $\mathrm{U}$ occurrences in shallow wells in and near the center of 
the basing to evaporative concentration (Fujii and Swain 1995). However, remobilization of $U$ from redox fronts in the system does not appear to cause the vast majority of high $\mathrm{U}$ concentrations in groundwater. About $8 \%$ of wells had mixed redox conditions, where DO $>0.5 \mathrm{mg} / \mathrm{L}$ and manganese or iron was above $50 \mu \mathrm{g} / \mathrm{L}$. Wells with mixed redox conditions had a wide range of $\mathrm{U}$ concentrations $(0.04$ to $503 \mu \mathrm{g} / \mathrm{L}$; median $=16.0 \mu \mathrm{g} / \mathrm{L})$. However, wells in the eastern alluvial fans that represent the bulk of the used groundwater resource in the ESJV were generally oxic.

Dissolved U species in oxic groundwater samples (262 oxic wells had measurable U) were calculated using PHREEQC. More than $85 \%$ of the dissolved U in almost all groundwater samples was in the form of ternary complexes of uranyl carbonate with calcium $\left(\mathrm{Ca}_{2} \mathrm{UO}_{2}\left(\mathrm{CO}_{3}\right)_{3}^{0}, \mathrm{CaUO}_{2}\left(\mathrm{CO}_{3}\right)_{3}^{-2}\right)$ and was primarily in the form of the neutral calcium-uranyl-carbonate complex. Calcium-uranyl-carbonate species comprised less than $50 \%$ of the dissolved $U$ in just $2 \%$ of the oxic groundwater samples. Phosphate complexes comprised less than $1 \%$ in all groundwater samples. Speciation calculations indicate that magnesium-uranyl complexes are present $\left(\mathrm{MgUO}_{2}\left(\mathrm{CO}_{3}\right)_{3}^{-2}\right)$, but generally comprise about $1 \%$ and at most $5 \%$ of dissolved $\mathrm{U}$.

Strong correlations between $\mathrm{U}$ and bicarbonate (Figure 4; Spearman's rho $=0.74, P$-value $<0.001$ ) and $\mathrm{U}$ and calcium (Spearman's rho $=0.77, P$-value $<0.001)$ concentrations are consistent with speciation calculations. Although the species is a complex between uranyl and the carbonate anion, the formation of the species is likely between uranyl and any one of the three inorganic carbon ions $\left(\mathrm{H}_{2} \mathrm{CO}_{3}^{0 *}, \mathrm{HCO}_{3}^{-}, \mathrm{CO}_{3}^{-2}\right)$. The predominant form of DIC species in water is $\mathrm{pH}$ dependent. Groundwater from this study had $\mathrm{pH}$ values that ranged from 6.7 to 9.7 (median $\mathrm{pH}=7.6$ ), and bicarbonate is the principal form of DIC in that $\mathrm{pH}$ range (Appelo and Postma 1996).

$$
\begin{gathered}
\mathrm{UO}_{2}^{+2}+2 \mathrm{Ca}^{+2}+3 \mathrm{HCO}_{3}^{-} \\
\leftrightarrow \mathrm{Ca}_{2} \mathrm{UO}_{2}\left(\mathrm{CO}_{3}\right)_{3}^{0}+3 \mathrm{H}^{+} \\
\log K=-0.29 \text { (modified from } \\
\quad \text { Dong and Brooks [2006]) }
\end{gathered}
$$

Calcium in groundwater is mostly a result of the dissolution of minerals in the soil zone and partly from the application of soil amendments and fertilizers at the land surface. Calcium is present in all sediments, primarily as plagioclase feldspar, and most soils contain some calcite. In many agricultural parts of the valley, gypsum is often added to irrigated soils to promote infiltration and nitrate fertilizers often contain calcium (Jurgens et al. 2008).

Strong correlations between $U$ and bicarbonate and the results of the $\mathrm{U}$ extractions indicate that high concentrations of $\mathrm{U}$ in shallow groundwater were at least partially mobilized from adsorption sites from shallow sediments. Adsorption of $\mathrm{U}$ to sediments is mainly dependent on $\mathrm{pH}$ and the concentration of DIC (Hsi and Langmuir 1985; Waite et al. 1994; Davis et al. 2004). Calculations from

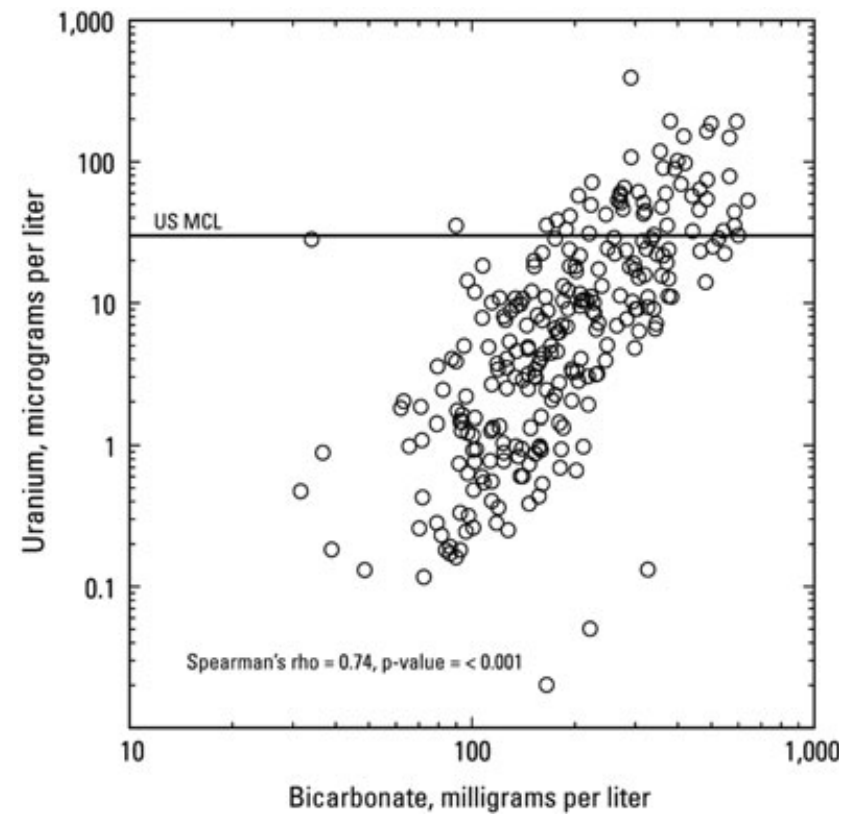

Figure 4. Relation between uranium and bicarbonate in oxic groundwater in the eastern San Joaquin Valley, California.

PHREEQC predict that U(VI) minerals are highly undersaturated in the 262 groundwater samples, suggesting that $\mathrm{U}$ concentrations are most likely controlled by adsorption processes. Adsorption of $\mathrm{U}(\mathrm{VI})$ is strongest at near circumneutral $\mathrm{pH}$ values while high $\mathrm{pH}$ values tend to weaken adsorption of $\mathrm{U}(\mathrm{VI})$. However, high concentrations of DIC can limit the adsorption of U. In the ESJV, U decreases with increasing $\mathrm{pH}$ (Spearman's rho $=-0.23$, $P$-value $<0.001$; Figure 5). Consequently, $\mathrm{U}$ is highest in groundwater with more neutral $\mathrm{pH}$ values and higher concentrations of DIC, whereas groundwater with low U tends to have higher $\mathrm{pH}$ values and lower concentrations of DIC.

To demonstrate the effect that DIC has on U(VI) adsorption, the SCM of Waite et al. (1994) was used to calculate the dissolved $\mathrm{U}(\mathrm{VI})$ concentrations at different total DIC concentrations and $\mathrm{pH}$ values observed in groundwater (Figure 5; dashed lines). Dissolved U(VI) was at least an order of magnitude greater in the presence of high concentrations of DIC $(0.01 \mathrm{M})$ than at lower concentrations of DIC $(0.001 \mathrm{M})$. However, the SCM tended to underpredict $\mathrm{U}(\mathrm{VI})$ concentrations in groundwater at high concentrations of DIC. Fox et al. (2006) showed that the presence of calcium in solution can also reduce the adsorption of $\mathrm{U}(\mathrm{VI})$ to iron oxyhydroxides under conditions that favor the formation of the neutral calciumuranyl-carbonate complex, $\mathrm{Ca}_{2} \mathrm{UO}_{2}\left(\mathrm{CO}_{3}\right)_{3}^{0}$. By including a typical calcium concentration $(50 \mathrm{mg} / \mathrm{L})$ in each model, the predicted behavior of $\mathrm{U}(\mathrm{VI})$ in equilibrium with iron oxyhydroxides is remarkably similar to U and DIC concentrations observed in ESJV groundwater, especially for higher concentrations of U(VI) and DIC (Figure 5; 


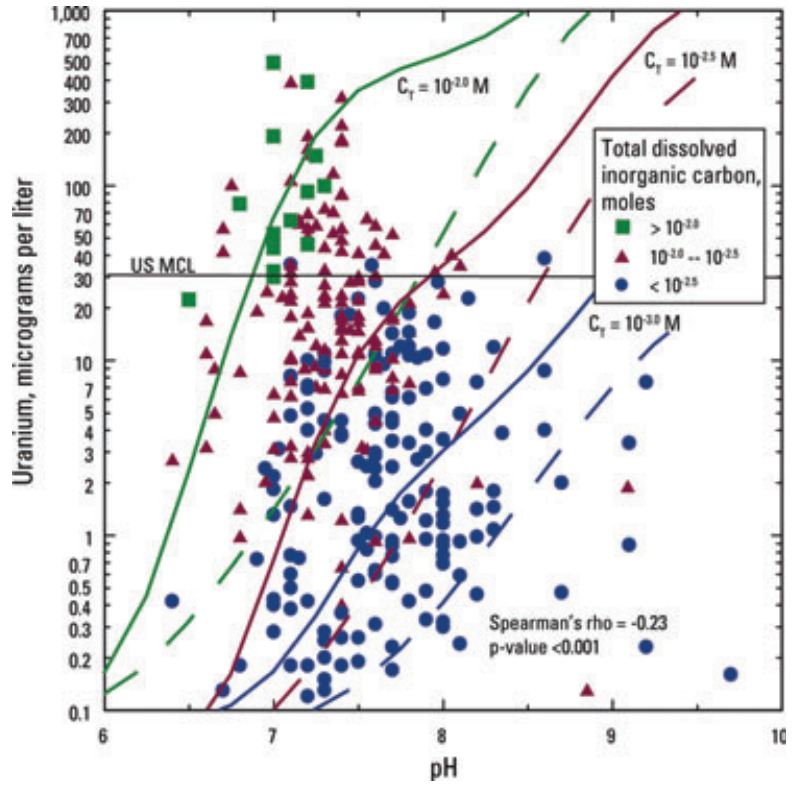

Figure 5. Relation between pH and uranium [U(VI)] in groundwater in the eastern San Joaquin Valley, California. Symbols are colored according to the concentration of total dissolved inorganic carbon (DIC). Dashed lines are equilibrium concentrations of dissolved $U(V I)$ from a surface complexation model (SCM) based on the work of Waite et al. (1994). Solid lines are equilibrium concentrations of U(VI) from the same SCM with a calcium concentration of $1.2475 \mathrm{mmol} / \mathrm{L}$. Each line color represents the equilibrium concentration of $U(V I)$ for different concentrations of total DIC. $T=25^{\circ} \mathrm{C} ; I=0.1 \mathrm{M} ; \mathrm{U}(\mathrm{VI})$ total $=0.01 \mathrm{mmol} / \mathrm{L}$; $\mathrm{Fe}=80 \mathrm{mmol} / \mathrm{L}$ (average concentration of 10 aquifer core samples using 0.5 M HCl-hydroxylamine extraction). Site densities were from Waite et al. (1994): total sites 0.875 moles $/$ mole of $\mathrm{Fe}$; strong sites $=0.0018 \mathrm{moles} / \mathrm{mole}$ of $\mathrm{Fe}$; and weak sites $=\mathbf{0 . 8 7 3 2} \mathrm{moles} / \mathrm{mole}$ of $\mathrm{Fe}$.

solid lines). These results are also consistent with speciation calculations that predict the calcium-uranyl-carbonate species to predominate in ESJV groundwater.

\section{Long-Term Bicarbonate Trends and Relation to Land Use}

Comparison between data from Mendenhall et al. (1916) and data from the USGS-GAMA and USGShistorical datasets showed that concentrations of bicarbonate in ESJV groundwater have increased over the last 100 years (Figure 6). In 1910, the median bicarbonate concentration of groundwater in the ESJV was $119 \mathrm{mg} / \mathrm{L}$. The median bicarbonate concentration from this study was $178 \mathrm{mg} / \mathrm{L}$ and is statistically greater than concentrations in 1910 (Kruskal-Wallis rank sum test, $P$-value $<0.001$ ).

Wells from 100 years ago were typically shallower. The median well depth in Mendenhall's dataset was 95 feet compared to 205 feet in this study. Of course, the water table was not as deep 100 years ago as it is in many parts of the valley today. Most wells 100 years ago were probably perforated in shallower parts of the groundwater system than modern wells because of construction limitations and because the yield and quality of groundwater at those depths were sufficient for most purposes (Mendenhall et al. 1916).

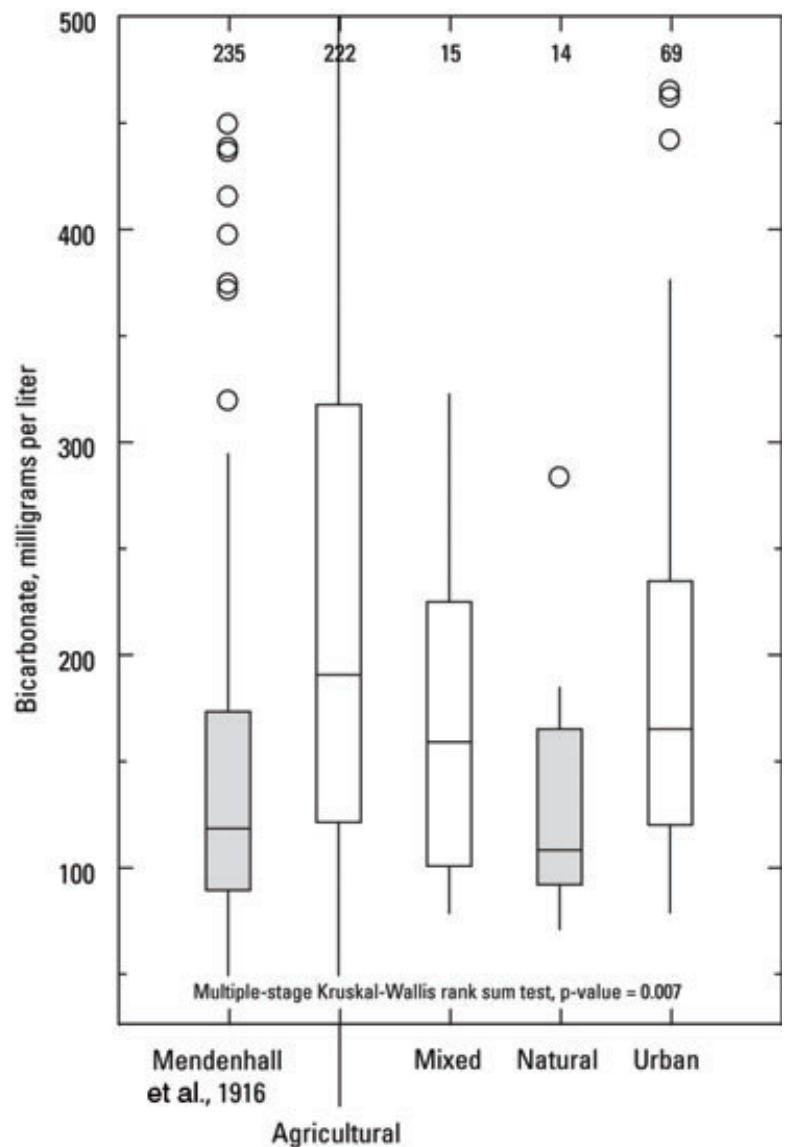

Land-use Classification

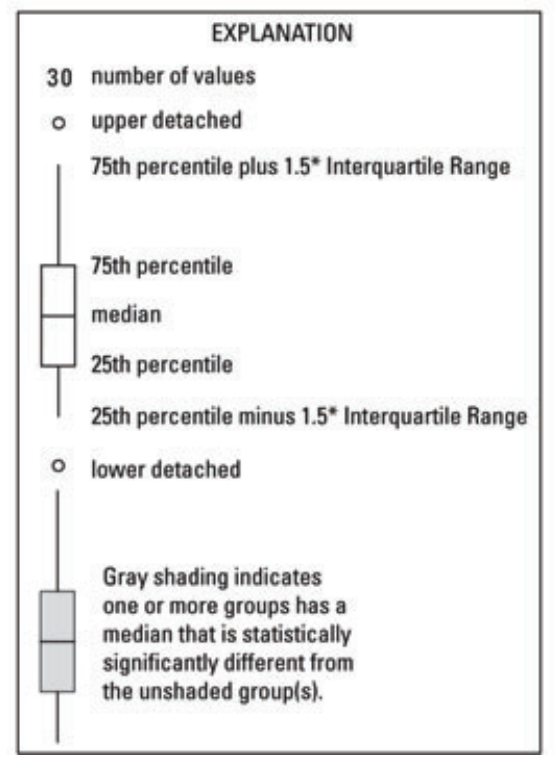

Figure 6. Bicarbonate concentrations in groundwater in 1910 (Mendenhall et al. 1916) and from this study (GAMA + USGS historical [since 1989]) among different land uses surrounding the wells in the eastern San Joaquin Valley, California. The mixed use category was assigned to wells where neither agricultural, urban, or natural land uses were more than $50 \%$ of the land surrounding the well.

The increase in bicarbonate concentration over the last 100 years is related to land-use patterns. Bicarbonate concentrations in wells surrounded predominantly 
by natural land use (median $=108 \mathrm{mg} / \mathrm{L}$ ) and in wells sampled in 1910 (median $=119 \mathrm{mg} / \mathrm{L}$ ) were significantly lower than bicarbonate concentrations in wells surrounded predominantly by agricultural (median $=$ $191 \mathrm{mg} / \mathrm{L})$, urban $($ median $=166 \mathrm{mg} / \mathrm{L})$, and mixed $($ median $=160 \mathrm{mg} / \mathrm{L}$ ) land uses (Figure 6) (multiple stage Kruskal-Wallis rank sum test, $P$-value $<0.001)$. Although many of the wells sampled in 1910 were in agricultural areas, large-scale irrigation had not yet been developed, and thus water use on the landscape more closely resembled natural conditions.

Urban areas in the ESJV are typically surrounded by agricultural land, and urban groundwater pumping is areally concentrated. Consequently, bicarbonate concentrations beneath urban areas are likely affected by adjacent agricultural land use, which tends to be associated with higher bicarbonate concentrations.

\section{Connection between Increased Bicarbonate Concentrations and Irrigation}

The relations between bicarbonate concentrations, $P \mathrm{CO}_{2}$, recharge temperature, and depth in groundwater in the ESJV suggest that high bicarbonate concentrations in shallow groundwater are the result of groundwater recharge by water that has percolated through irrigated soils. $P \mathrm{CO}_{2}$ in the soil zone can range from equal to atmospheric $\mathrm{PCO}_{2}(0.035 \%)$ to greater than 100 times atmospheric $\mathrm{PCO}_{2}$, and is generally positively correlated with soil moisture, soil temperature, and plant growth (e.g., Russell 1973). In arid to semiarid climates, plant growth and microbial decomposition of soil organic matter are generally limited by low soil moisture. Addition of water via precipitation or irrigation results in a rise in biological activity and thus a rise in soil zone $\mathrm{PCO}_{2}$.

Equilibrium $\mathrm{PCO}_{2}$ values were calculated from groundwater major ion chemistry and $\mathrm{pH}$ data using PHREEQC. Groundwater $\mathrm{PCO}_{2}$ ranged from 0.1 to 430 times atmospheric $\mathrm{PCO}_{2}$ and decreased with depth below the water table (Spearman's rho $=-0.51, P$-value $<$ 0.001; Figure 7). Most groundwater within 50 feet of the water table had $\mathrm{PCO}_{2}$ pressures greater than 40 times atmospheric $\mathrm{PCO}_{2}$, indicating that the biological activity within the soil zone has influenced the chemistry of recent recharge.

In addition, $\mathrm{PCO}_{2}$ pressures were higher in groundwater beneath agricultural land than in groundwater beneath other land uses (multiple stage Kruskal-Wallis rank sum test, $P$-value $<0.001$; Figure 7). The median $\mathrm{PCO}_{2}$ pressure for groundwater beneath agricultural land was $10^{-2.1}$ atmospheres (atm) or approximately 22 times atmospheric concentrations. The median $\mathrm{PCO}_{2}$ pressure for groundwater beneath other land uses was $10^{-2.5}$ atm or approximately nine times atmospheric concentrations. $\mathrm{pH}$ was not collected in data from Mendenhall et al. (1916), and therefore, $\mathrm{PCO}_{2}$ pressures could not be directly compared. However, groundwater beneath natural land had similar bicarbonate concentrations to groundwater from 100 years

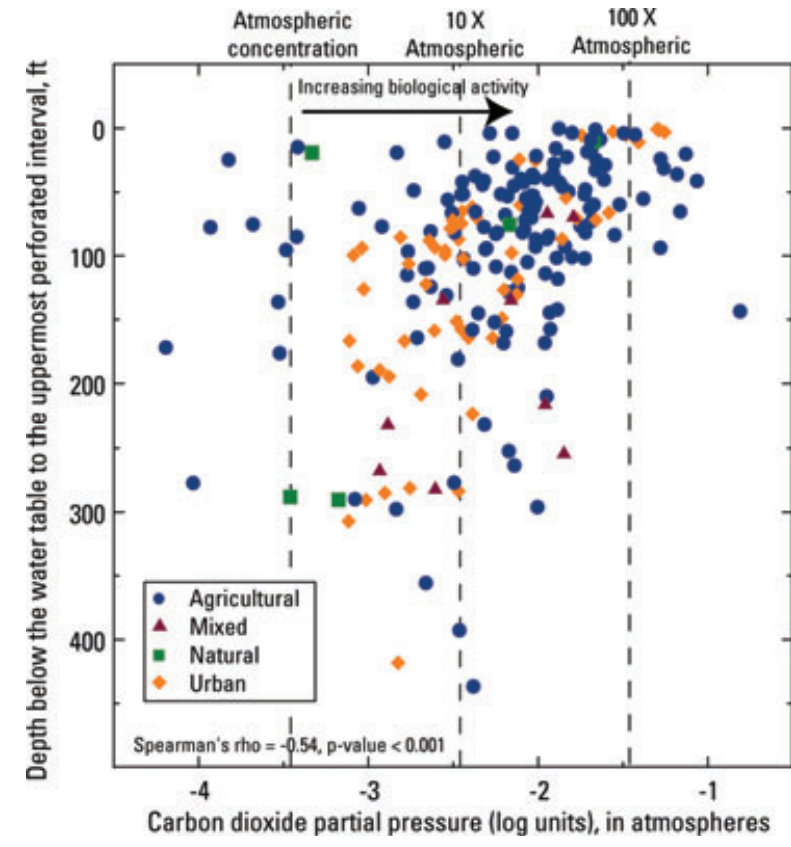

Figure 7. Relation between calculated equilibrium carbon dioxide partial pressures in groundwater and depth below the water table to the uppermost perforated interval in the eastern San Joaquin Valley, California.

ago and $\mathrm{PCO}_{2}$ pressures beneath natural land were lowest among all land uses (median $=10^{-3.0}$ or approximately three times atmospheric concentrations). Therefore, the increase in bicarbonate concentrations in shallow groundwater over the last 100 years likely resulted from recharge water having higher $\mathrm{PCO}_{2}$ pressures as a result of irrigation.

Higher $\mathrm{PCO}_{2}$ pressures can also cause the dissolution of carbonate minerals, namely calcite, within the soil zone (Appelo and Postma 1996). Calcite is present in most soils in the ESJV, but is generally much less than $5 \%$ (Schoups et al. 2005) and calcite was below detectable levels $(0.01 \%)$ in core from Modesto, California (Jurgens et al. 2008). Bicarbonate and calcium (and uranium) were correlated with increasing calcite saturation (log ratio of the ion activity product to the equilibrium solubility constant). Most groundwater with elevated and high concentrations of $\mathrm{U}(\mathrm{U}>15 \mu \mathrm{g} / \mathrm{L})$ was saturated with calcite $($ median $=0.13)$, whereas groundwater with lower $\mathrm{U}$ concentrations $(\mathrm{U}<15 \mu \mathrm{g} / \mathrm{L})$ was mostly undersaturated (median $=-0.16$ ). The dissolution of calcite under high $\mathrm{P}_{2}$ pressures could give rise to increases in bicarbonate and calcium concentrations with concomitant high calcite saturation in recharge water. Recent research also shows that calcite can accommodate uranyl in its structure and that the occurrence of uranyl in calcite formed in nearsurface environments may be more common than previously thought (Kelly et al. 2006). Although the amount of $U$ from soil calcite that would potentially contribute to groundwater is unknown, extraction results and extremely low abundance of calcite in the aquifer sediments suggest that calcite dissolution may not be an important source of 
$\mathrm{U}$ to groundwater. Furthermore, the results of the extraction experiments indicated that the amount of $U$ mobilized from adsorption sites would likely be sufficient to account for the increase in dissolved $\mathrm{U}$ concentrations in groundwater.

Higher recharge temperatures, calculated from dissolved noble gas concentrations, are associated with higher $P \mathrm{CO}_{2}$ pressures (and bicarbonate) in groundwater (Spearman's rho $=0.49, P$-value $\leq 0.001$; Figure 8 ). Calculated median recharge temperatures were one degree higher $\left(18.8^{\circ} \mathrm{C}\right)$ for wells surrounded by agricultural land than for those surrounded by urban, natural, and mixed land (multiple stage Kruskal-Wallis rank sum test, $P$ value $<0.02$ ). High recharge temperatures and high $\mathrm{PCO}_{2}$ pressures are consistent with recharge derived from summer irrigation, as would be found in agricultural areas in the ESJV. Under natural conditions, recharge occurred almost entirely during winter months (November through May) and therefore recharge temperatures were likely more influenced by winter air temperatures. Most of the recharge now occurs from the application of irrigation water during the summer months when air temperatures are highest.

Recharge temperatures and $\mathrm{PCO}_{2}$ pressures were positively correlated to total dissolved solids (TDS) and $\delta^{18} \mathrm{O}$. As stated earlier, the acidity derived by the rise in $\mathrm{PCO}_{2}$ pressures in the soil zone is buffered by the dissolution of minerals (mainly plagioclase), such that the primary products are an increase in $\mathrm{pH}$, formation of bicarbonate, and addition of cations to the residual water. Consequently, higher $\mathrm{PCO}_{2}$ pressures will tend to lead to increases in these weathering products and in the overall TDS of the water. Calculated $P \mathrm{CO}_{2}$ pressures (and $\mathrm{U}$ ) were correlated with all of the major cations in ESJV groundwater. TDS has also increased in the last 100 years. The median TDS in wells from 1910 was $210 \mathrm{mg} / \mathrm{L}$ and was $311 \mathrm{mg} / \mathrm{L}$ in the USGS-GAMA and USGS-historical dataset (Kruskal-Wallis rank sum test, $P$-value $<0.001)$. Correlations with $\delta^{18} \mathrm{O}$ also suggest that the increase in bicarbonate concentrations may be partly because of evaporation of irrigation water during the summer growing season; although strong evaporation trends were not evident from stable isotope values.

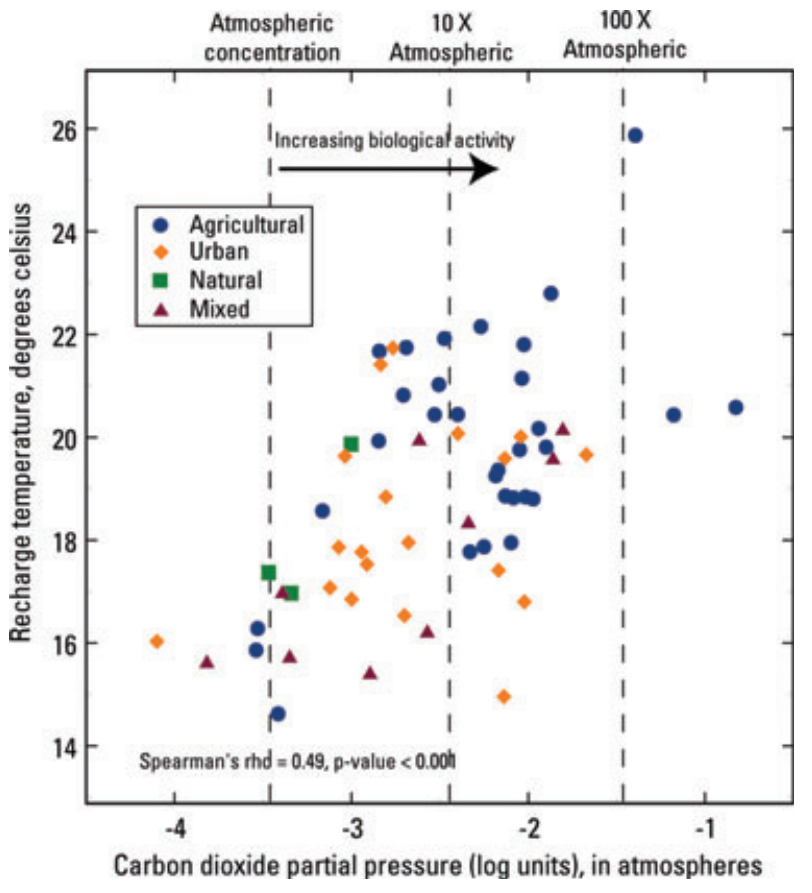

Figure 8. Relation between recharge temperature and the partial pressure of carbon dioxide in groundwater beneath different land-use settings in the eastern San Joaquin Valley, California.

\section{Recent Uranium Trends}

Recent U trends in wells from the CDPH database were evaluated using data for wells that were sampled from January 1, 1990, to December 31, 2005. This time period provided an even split in years (8), and similar number of wells analyzed during the two time periods (Table 2). For wells with more than one $\mathrm{U}$ analysis, the median activity from each well was used to calculate population statistics. The number of wells having at least one $\mathrm{U}$ sample above the CA-MCL of $20 \mathrm{pCi} / \mathrm{L}$ increased from 38 for samples collected from 1990 to 1998 to 56 from 1998 to 2006 (Table 2).

$\mathrm{U}$ data were available in both time periods for 317 wells. The median activity of $U$ in these wells increased from $4.3 \mathrm{pCi} / \mathrm{L}$ between 1990 and 1998 to $5.0 \mathrm{pCi} / \mathrm{L}$ between 1998 and 2006 (signed-rank test, $P$-value < 0.001). The average change in concentration was 1.2

\section{Table 2}

Summary of Uranium Concentrations in Groundwater from Public-Supply Wells Sampled between 1990 and 2006 in Eastern San Joaquin Valley, California; California Department of Public Health

Uranium (pCi/L)

\begin{tabular}{|lccccc} 
Uranium Date Range & Number of Wells & Minimum & Median & Maximum & Number of Wells with U > 20 pCi/L \\
\hline $1990-2006$ & 848 & $<1$ & 3.7 & 63.9 & $81(9.6 \%)$ \\
$1990-1998$ & 556 & $<1$ & 3.6 & 49.4 & $38(6.8 \%)$ \\
$1998-2006$ & 610 & $<1$ & 4.2 & 102 & $56(9.2 \%)$ \\
\hline
\end{tabular}

Note: Percentage of wells in parentheses. 
$\mathrm{pCi} / \mathrm{L}$. U activity increased by more than $0.2 \mathrm{pCi} / \mathrm{L}$ in $53 \%$ of the wells, decreased by more than $0.2 \mathrm{pCi} / \mathrm{L}$ in $35 \%$ of the wells, and changed by less than $0.2 \mathrm{pCi} / \mathrm{L}$ in the remaining $12 \%$ of wells. These results indicate that $\mathrm{U}$ has increased in the majority of PSWs in the ESJV. Bicarbonate concentrations in paired samples also increased for the same time period by about $2.7 \mathrm{mg} / \mathrm{L}$. Wells that had increased $\mathrm{U}$ concentrations had a median increase in bicarbonate of $6.3 \mathrm{mg} / \mathrm{L}$, whereas wells that had decreased $\mathrm{U}$ concentrations had a median decrease in bicarbonate of $1.6 \mathrm{mg} / \mathrm{L}$. These results indicate that increased $\mathrm{U}$ concentrations are accompanied with increased bicarbonate concentrations.

The median $\mathrm{U}$ concentration for unpaired samples also increased over the 16-year period (Table 2). The median for these samples increased by $0.6 \mathrm{pCi} / \mathrm{L}$ for the time period evaluated.

\section{Conclusions}

Development of the groundwater resource since the 1850s has caused two major changes that have resulted in uranium concentrations above drinking water standards in domestic and PSWs in the ESJV: (1) changes in the chemistry of recharge water and (2) increases in the rate of downward groundwater flow.

ESJV sediments have comparatively high concentrations of uranium and a fraction of this uranium is readily leachable by bicarbonate solutions. Uranium is strongly correlated with calcium and bicarbonate, the principal form of DIC in groundwater. Speciation calculations indicate that the primary form of $\mathrm{U}$ in oxic groundwater is a calcium-uranyl-carbonate complex. The results of the $\mathrm{U}$ extractions and co-occurrence of elevated concentrations of $\mathrm{U}$, bicarbonate, and calcium are consistent with results from the SCM, suggesting that U likely has been leached from adsorption sites on mineral surfaces in sediment. Because bicarbonate concentrations have increased over the last 100 years, it is reasonable to assume that dissolved $\mathrm{U}$ has also increased during this period.

The increase in bicarbonate in groundwater over the last 100 years is primarily related to the agricultural development of the ESJV. Bicarbonate concentrations in groundwater have increased in response to an increase in recharge and the growth of crops in agricultural areas and, to lesser extent, the growth of landscape plants and grasses in urban areas. Both recharge and the growth of crops occur mostly during the summer growing season when temperatures are warmest. Consequently, groundwater beneath agricultural land tends to have higher recharge temperatures and higher $P \mathrm{CO}_{2}$ pressures. Ultimately, the increase in bicarbonate concentrations in recharge water has led to the widespread occurrence of high $U$ in shallow groundwater.

Groundwater pumping, primarily from deeper parts of the aquifer system, and increased recharge from the application of irrigation water have increased the downward movement of groundwater. Consequently, constituents that enter the groundwater system at shallow depths are moved downward at a faster rate than would be expected under natural conditions. Shallow high $\mathrm{U}$ groundwater has thus moved downward, resulting in increasing U in PSWs. The overall increase in the median $\mathrm{U}$ concentration for all wells is small $(0.6 \mathrm{pCi} / \mathrm{L})$, but the percentage of wells with at least one $\mathrm{U}$ analysis greater than $20 \mathrm{pCi} / \mathrm{L}$ (CA-MCL) has increased from $7 \%$ to $9 \%$ in just 16 years. Continued irrigation and pumping in the ESJV will likely be followed by additional U increases in PSWs.

This paper also shows that irrigation and development of lands for agricultural and urban uses can mobilize inorganic contaminants that may otherwise be sequestered under natural conditions. The results of this paper therefore could have broader implications for other agriculturally based arid and semiarid regions around the world.

\section{Acknowledgments}

This work was supported by the California State Water Resources Control Board with help from landowners and water purveyors throughout the San Joaquin Valley. We thank the three anonymous reviewers for their constructive comments and helpful suggestions. Major improvements also resulted from reviews by Robert A. Zielinski and Steven P. Phillips. We also thank David L. Parkhurst for his helpful guidance with the surface complexation model used in this paper.

\section{References}

Aeschbach-Hertig, W., F. Peeters, U. Beyerle, and R. Kipfer. 2000. Paleotemperature reconstruction from noble gases in groundwater taking into account equilibration with entrapped air. Nature 405, no. 6790: 1040-1044.

Aeschbach-Hertig, W., F. Peeters, U. Beyerle, and R. Kipfer. 1999. Interpretation of dissolved atmospheric noble gases in natural waters. Water Resources Research 35, no. 9: 2779-2792.

Appelo, C.A.J., and D. Postma. 1996. Geochemistry, Groundwater, and Pollution. Rotterdam, The Netherlands: A.A. Balkema.

Ashton, A. 2006. Shuttered wells to service City again; filters, diluting tanks to treat tainted water. The Modesto Bee, September 19, 2006, Local News, B2.

Bartow, J.A. 1991. The Cenozoic evolution of the San Joaquin Valley, California. USGS Professional Paper 1501. Reston, Virginia: USGS.

Bayer, R., P. Schlosser, G. Bon̈isch, H. Rupp, F. Zaucker, and G. Zimmek. 1989. Performance and blank components of a mass spectrometric system for routine measurement of helium isotopes and tritium by the $3 \mathrm{He}$ in growth method. In Sitzungsberichte der Heidelberger Akademie der Wissenschaften Mathematisch-naturwissenschaftliche Klasse, Jahrgang, vol. 5, 241-279. Heidelberg, Gemany: Springer Verlag.

Belitz, K., N.M. Dubrovsky, K.R. Burow, B. Jurgens, and T. Johnson. 2003. Framework for a ground-water quality monitoring and assessment program for California. USGS Water Resources Investigations Report 03-4166. Reston, Virginia: USGS. 
Bennett, G.L.V., K. Belitz, and B.M. Dawson. 2006. California GAMA Program: Ground water quality data in the northern San Joaquin Basin study unit, 2005. USGS Data Series 196. Reston, Virginia: USGS.

Bernhard, G., G. Geipel, T. Reich, V. Brendler, S. Amayri, and H. Nitsche. 2001. Uranyl(VI) carbonate complex formation: Validation of the $\mathrm{Ca}_{2} \mathrm{UO}_{2}\left(\mathrm{CO}_{3}\right)_{3}$ (aq.) species. Radiochimica Acta 89, no. 8: 511-518.

Bertoldi, G.L., R.H. Johnston, and K.D. Evenson. 1991. Ground water in the Central Valley, California-A summary report. USGS Professional Paper 401-A. Reston, Virginia: USGS.

Beyerle, U., W. Aeschbach-Hertig, D.M. Imboden, H. Baur, T. Graf, and R. Kipfer. 2000. A mass spectrometric system for the analysis of noble gases and tritium from water samples. Environmental Science and Technology 34, no. 10: 2042-2050.

Burow, K.R., J.L. Shelton, and N.M. Dubrovsky. 2008. Regional nitrate and pesticide trends in ground water in the eastern San Joaquin Valley, California. Journal of Environmental Quality 37, no. 5: 249-263.

Burow, K.R., J.L. Shelton, J.A. Hevesi, and G.S. Weissmann. 2004. Hydrogeologic characterization of the Modesto area, San Joaquin Valley, California. USGS Scientific Investigations Report 2004-5232. Reston, Virginia: USGS.

Burow, K.R., J.L. Shelton, and N.M. Dubrovsky. 1998. Occurrence of nitrate and pesticides in ground water beneath three agricultural land-use settings in the eastern San Joaquin Valley, California, 1993-1995. USGS Water Resources Investigations Report 97-4284. Reston, Virginia: USGS.

Burton, C.A., and Belitz, K., 2008. Ground water quality data in the southeastern San Joaquin Valley 2005-2006: Results from the California GAMA program. USGS Data Series 351. Reston, Virginia: USGS.

Catalano, J.G., and G.E. Brown. 2005. Uranyl adsorption onto montmorillonite: Evaluation of binding sites and carbonate complexation. Geochemica et Cosmochimica Acta 69, no. 12: 2995-3005.

Cey, B.D., G.B. Hudson, J.E. Moran, and B.R. Scanlon. 2008. Impact of artificial recharge on dissolved noble gases in groundwater in California. Environmental Science and Technology 42, no. 4: 1017-1023.

Conover, W.L. 1980. Practical Nonparametric Statistics, 2nd ed. New York: John Wiley \& Sons.

Davis, G.H., J.H. Green, F.H. Olmsted, and D.W. Brown. 1959. Ground water conditions and storage capacity in the San Joaquin Valley, California. USGS Water-Supply Paper 1469. Reston, Virginia: USGS.

Davis, J.A., D.E. Meece, M. Kohler, and G.P. Curtis. 2004. Approaches to surface complexation modeling of uranium(VI) adsorption on aquifer sediments. Geochimica et Cosmochimica Acta 68, no. 18: 3621-3641.

Davis, J.A., and G.P. Curtis. 2004. Application of Surface Complexation Modeling to Describe Uranium (VI) Adsorption and Retardation at the Uranium Mill Tailings Site at Naturita, Colo. Rockville, Maryland: US Nuclear Regulatory Commission. http://www.nrc.gov/reading-rm/doccollections/nuregs/contract/cr6820/.

Domagalski, J.D. 1997. Pesticides in surface and ground water of the San Joaquin-Tulare basins, California: Analysis of available data, 1966 through 1992. USGS Water-Supply Paper 2468. Reston, Virginia: USGS.

Dong, W., and S.C. Brooks. 2006. Determination of the formation constants of ternary complexes of uranyl and carbonate with alkaline earth metals $\left(\mathrm{Mg}^{2+}, \mathrm{Ca}^{2+}, \mathrm{Sr}^{2+}\right.$, and $\left.\mathrm{Ba}^{2+}\right)$ using anion exchange method. Environmental Science and Technology 40, no. 15: 4689-4695.

Dubrovsky, N.M., C.K. Kratzer, Brown, L.R., J.M. Gronberg, and K.R. Burow. 1998. Water quality in the San JoaquinTulare Basins, California, 1992-1995. USGS Circular 1159. Reston, Virginia: USGS.

Dzombak, D.A., and F.M.M. Morel. 1990. Surface Complexation Modeling - Hydrous Ferric Oxide. New York: John Wiley \& Sons.

Faunt, C.C., ed. 2009. Ground water availability and flow in California's Central Valley. USGS Professional Paper 1766. Reston, Virginia: USGS.

Focazio, M.J., D. Tipton, S.D. Shapiro, and L.H. Geiger. 2006. The chemical quality of self-supplied domestic well water in the United States. Ground Water Monitoring and Remediation 26, no. 3: 92-104.

Fox, P.M., J.A. Davis, and J.M. Zachara. 2006. The effect of calcium on aqueous(VI) speciation and adsorption to ferrihydrite and quartz. Geochimica et Cosmochimica Acta 70, no. 6: 1379-1387.

Fujii, R., and W.C. Swain. 1995. A real distribution of selected trace elements, salinity, and major ions in shallow ground water, Tulare Basin, southern San Joaquin Valley, California. USGS Water-Resources Investigations Report 95-4048. Reston, Virginia: USGS.

Gilliom, R.J., J.E. Barbash, C.G. Crawford, P.A. Hamilton, J.D. Martin, N. Nakagaki, L.H. Nowell, J.C. Scott, P.E. Stackelberg, G.P. Thelin, and D.M. Wolock. 2006. The quality of our nation's waters: Pesticides in the nation's streams and ground water, 1992-2001. USGS Circular 1291. Reston, Virginia: USGS.

Grenthe I., J. Fuger, R.J.M. Konings, R.J. Lemire, A.J. Muller, C. Nguyen-TRUNG, and H. Wanner. 1992. Chemical Thermodynamics of Uranium. Amsterdam, The Netherlands: Elsevier.

Gronberg, J.A., N.M. Dubrovsky, C.R. Kratzer, J.L. Domagalski, L.R. Brown, and K.R. Burow. 1998. Environmental setting of the San Joaquin-Tulare basins, California. USGS Water-Resources Investigations Report 97-4205. Reston, Virginia: USGS.

Helsel, D.R., and R.M. Hirsch. 2002. Statistical methods in water resources. In USGS Techniques of the Water-Resources Investigations, Book4, Chap. A3. Reston, Virginia: USGS.

Hsi C.D., and D. Langmuir. 1985. Adsorption of uranyl onto ferric oxyhydroxides: Application of the surface complexation site-binding model. Geochimica et Cosmochimica Acta 49, no. 9: 1931-1941.

Hutson, S.S., N.L. Barber, J.F. Kenny, K.S. Linsey, D.S. Lumia, and M.A. Maupin. 2004. Estimated use of water in the United States in 2000. USGS Circular 1268. Reston, Virginia: USGS.

Johnson, T.D., and K. Belitz. 2009. Assigning land use to supply wells for the statistical characterization of regional groundwater quality: Correlating urban land use and VOC occurrence. Journal of Hydrology 370, no. 1-4: 100-108.

Jurgens, B.C., P.B. Mcmahon, F.H. Chapelle, and S.M. Eberts. 2009. An Excel ${ }^{\circledR}$ workbook for identifying redox processes in ground water. USGS OpenFile Report 2009-1004. Reston, Virginia: USGS. http://pubs.usgs.gov/of/2009/1004/ (accessed July 6, 2009).

Jurgens, B.C., K.R. Burow, B.A. Dalgish, and J.L. Shelton. 2008. Hydrogeology, water chemistry, and factors affecting the transport of contaminants in the zone of contribution to a public-supply well in Modesto, eastern 
San Joaquin Valley, California. USGS Scientific Investigations Report 2008-5156. Reston, Virginia: USGS. http://pubs.usgs.gov/sir/2008/5156/ (accessed July 6, 2009).

Kelly, S.D., E.T. Rasbury, S. Chattopadhyay, A.J. Kropf, and K.M. Kemner. 2006. Evidence of a stable uranyl site in ancient organic-rich calcite. Environmental Science and Technology 38, no. 7: 2262-2268.

Kohler, M., D.M. Meece, G.P. Curtis, and J.A. Davis. 2004. Methods for estimating adsorbed uranium(VI) and distribution coefficients in contaminated sediments. Environmental Science and Technology 38, no. 1: 240-247.

Koterba, M.T., F.D. Wilde, and W.W. Lapham. 1995. Groundwater data-collection protocols and procedures for the National Water-Quality Assessment Program: Selection, installation and documentation of wells, and collection of related data. USGS Open-File Report 95-399. Reston, Virginia: USGS.

Landon, M.K., and K. Belitz. 2008. Ground water quality data in the central eastside San Joaquin Basin 2006: Results from the California GAMA program. USGS Data Series 325. Reston, Virginia: USGS.

Langmuir, D. 1978. Uranium solution-mineral equilibria at low temperatures with applications to sedimentary ore deposits. Geochimica et Cosmochimica Acta 42, no. 6: 547-569.

Londquist, C.J. 1981. Digital model of the unconsolidated aquifer system in the Modesto area, Stanislaus and San Joaquin Counties, California. USGS Water-Resources Investigations Report 81-12. Reston, Virginia: USGS.

Maupin, M.A., and N.L. Barber. 2005. Estimated withdrawals from principal aquifers in the United States-2000. USGS Circular 1279. Reston, Virginia: USGS.

Mcmahon, P.B., and F. Chapelle. 2008. Redox processes and water quality of selected principal aquifer systems. Ground Water 46, no. 2: 259-271.

Mendenhall, W.C., R.B. Dole, and H. Stabler. 1916. Ground water in the San Joaquin Valley. USGS Water-Supply Paper 398. Reston, Virginia: USGS.

Moore, K.B., B. Ekwurzel, B.K. Esser, G.B. Hudson, and J.E. Moran. 2006. Sources of groundwater nitrate revealed using residence time and isotope methods. Applied Geochemistry 21, no. 6: 1016-1029.

Nakagaki, N., and D.M. Wolock. 2005. Estimation of agricultural pesticide use in drainage basins using land cover maps and county pesticide data. USGS Open-File Report 05-1188. Reston, Virginia: USGS.

Nightingale, H. 1972. Nitrates in soil and groundwater beneath irrigated and fertilized crops. Soil Science 114, no. 4: 300-311.

Page, R.W. 1986. Geology of the fresh ground water basin of the Central Valley, California, with textural maps and section. USGS Professional Paper 1401-C. Reston, Virginia: USGS.

Page, R.W., and G.O. Balding. 1973. Geology and quality of water in the Modesto-Merced Area, San Joaquin Valley, California, with a brief section on hydrology. USGS WaterResources Investigations Report 6-73. Reston, Virginia: USGS.

Parkhurst, D.L., and C.A.J. Appelo. 1999. User's guide to PHREEQC (Version 2) - A computer program for speciation, batch-reaction, one-dimensional transport, and inverse geochemical calculations. USGS Water Resources Investigations Report 99-4259. Reston, Virginia: USGS.
Payne, T.E. 1999. Uranium (VI) interactions with mineral surfaces: controlling factors and surface complexation. Ph.D. diss., University New South Wales, Australia.

Phillips, S.P., D.L. Rewis, J.L. Shelton, K.R. Burow, and B. Jurgens. 2007. Hydrogeologic settings and ground water flow simulations of the San Joaquin Valley Regional Study Area, California. In Hydrogeologic Settings and Ground Water Flow Simulations for Regional Studies of the Transport of Anthropogenic and Natural Contaminants to Public-Supply Wells-Studies begun in 2001, sec. 4, ed. S.S. Paschke, USGS Professional Paper 1737-A. Reston, Virginia: USGS.

Phillips, J.D., J.S. Duval, and R.A. Ambroziak. 1993. National geophysical data grids; gamma-ray, gravity, magnetic, and topographic data for the conterminous United States. USGS Digital Data Series DDS-9. http:// crustal.usgs.gov/geophysics/gamma.html (accessed January 12, 2006).

Price, C.V., N. Nakagaki, K.J. Hitt, and R.M. Clawges. 2003. Mining GIRAS-improving on a national treasure of land use data. In Proceedings of the 23rd ESRI International Users Conference, July 7-11, 2003, Redlands, California.

Russell, E.W. 1973. Soil Conditions and Plant Growth. 10th ed. London: Longman.

Schmidt, K.D. and I. Sherman. 1987. Effect of irrigation on groundwater quality in California. Journal of Irrigation and Drainage Engineering 113, no. 1: 16-29.

Schoups, G., J.W. Hopmans, C.A. Young, J.A. Vrugt, W.W. Wallender, K.K. Tanji, and S. Panday. 2005. Sustainability of irrigated agriculture in the San Joaquin Valley, California. Proceedings of the National Academy of Sciences of the United States of America 102, no. 43: 15352-15356.

Scott, J.C. 1990. Computerized stratified random site selection approaches for design of a ground-water quality sampling network. USGS Water-Resources Investigations Report 90-4101. Reston, Virginia: USGS.

Shelton, J.L., M.S. Fram, and K. Belitz. 2009. Groundwater quality data for the Madera-Chowchilla study unit, 2008-Results from the California GAMA Program. USGS Data Series 455. Reston, Virginia: USGS.

Shelton, J.L., I. Pimentel, M.S. Fram, and K. Belitz. 2008. Ground water quality data in the Kern County Subbasin study unit, 2006-Results from the California GAMA program. USGS Data Series 337. Reston, Virginia: USGS.

U.S. Department of Agriculture. 2007. The 2007 census of agriculture. http://www.agcensus.usda.gov/Publications/2007/ Full_Report/index.asp (accessed July 15, 2009).

U.S. Environmental Protection Agency. 1980. Method 908.0-uranium in drinking water-radiochemical method. EPA-600-4-80-032. Washington, D.C.: U.S. Environmental Protection Agency.

Vogelmann, J.E., S.M. Howard, L. Yang, C.R. Larson, B.K. Wylie, and N. Van DRIEL. 2001. Completion of the 1990s National Land Cover Data Set for the conterminous Unites States from Landsat Thematic Mapper data and ancillary data sources. Photogrammetric Engineering \& Remote Sensing 67, no. 6: 650-662.

Waite, T.D., J.A. Davis, T.E. Payne, G.A. Waychunas, and N. Xu. 1994. Uranium(VI) adsorption to ferrihydrite: Application of a surface complexation model. Geochimica et Cosmochimica Acta 58, no. 24: 5465-5478.

Weissmann, G.S., G.L. Bennett, and A.L. Lansdale. 2005. Factors controlling sequence development on Quaternary 
fluvial fans, San Joaquin Basin, California. In Alluvial Fans: Geomorphology, Sedimentology, Dynamics, Special Publications, v. 251, ed. A.M. Harvey, A.E. Mather, and M. Stokes 169-186. London, UK: Geological Society.

Williamson, A.K., D.E. Prudic, and L.A. Swain. 1989. Ground water flow in the Central Valley, California. USGS Professional Paper 1401-D. Reston, Virginia: USGS.

Wright, M.T., K. Belitz, and T. Johnson. 2004. Assessing the susceptibility to contamination of two aquifer systems used for public water supply in the Modesto and Fresno metropolitan areas, California, 2001 and 2002. USGS Scientific Investigations Report 2004-5149. Reston, Virginia: USGS.

Zogorski, J.S., J.M. Carter, T. Ivahnenko, W.W. Lapham, M.J. Moran, B.L. Rowe, P.J Squillace, and P.L. Toccalino. 2006. Volatile organic compounds in the Nation's groundwater and drinking-water supply wells, USGS Circular 1292. Reston, Virginia: USGS. 